Laboratorio de Arte, 7-1994 http://dx.doi.org/10.12795/LA.1994.i07.09

\title{
APORTACIÓN A LA OBRA DEL ESCULTOR SEVILLANO JERÓNIMO ROLDÁN
}

\author{
POR JOSÉ RODA PEÑA
}

\begin{abstract}
Ofrecemos el perfil biográfico del imaginero sevillano Jerónimo Roldán (c.1701-c.1780), nieto del afamado Pedro Roldán, así como el análisis estilístico e iconográfico de su corta producción conocida. Finalmente, aportamos la documentación y estudio de una obra temprana e inédita, ya desaparecida; nos referimos a los tres "judíos" que esculpió en 1730 para la Hermandad de Nuestra Señora del Valle, de Sevilla.
\end{abstract}

We offer the biographical outline of Jerónimo Roldán (c.1701-c.1780), sevillian image-maker, who is famous Pedro Roldán's grandson. Also, a stylistic and iconographical research of his brief and know output is shored. Finally, we bring forward some documents and study of an early and unpublished work, now missing, which is three "jews" carved in 1730 for the Nuestra Señora del Valle Brotherhood, in Seville.

A pesar de las escasas noticias biográficas y artísticas que poseemos sobre el escultor dieciochesco Jerónimo Roldán, debió gozar de cierta reputación en su tiempo, si tenemos en cuenta que fue elegido para acometer un encargo triplemente regio, por su temática, ubicación y mecenazgo. Nos referimos al grupo escultórico de la Entrega de las llaves de Sevilla a San Fernando que corona la reja de la Cápilla Real de la Catedral hispalense, costeada por Carlos III, y erigida en 1773.

Nos proponemos reunir el corto caudal de datos que nos suministra la historiografía decimonónica y contemporánea sobre este escultor, así como incrementar su escueto catálogo artístico con una modesta aportación documental, pues la obra en cuestión, por desgracia, no se ha conservado.

\section{1.- NOTICIA BIOGRÁFICA.}

Jerónimo Tiburcio Roldán y Serrallonga nació en Sevilla hacia 1701, hijo del escultor Marcelino Roldán Villavicencio (1662-1709) y de su segunda esposa Josefa de Velasco y Serrallonga. Fue, por tanto, nieto de Pedro Roldán (1624-1699), sobrino de Luisa Roldán, "La Roldana" (1652-c.1704) y primo hermano de Pedro Duque Cornejo (1678-1757), por citar tan sólo tres egregios . 
eslabones de tan fecunda cadena familiar de imagineros. No es extraño que Jerónimo se decantara por la profesión escultórica, que también siguieron sus hermanos Marcelino y Diego.

Era un niño de pocos años cuando murió su padre, en junio de 1709. Quedó entonces, junto a sus cuatro hermanos, todos ellos menores de edad, bajo la tutela de su madre ${ }^{~}$. Evidentemente, su aprendizaje artístico no pudo llevarse a cabo en el taller paterno, por lo que se ha conjeturado que pudo efectuarlo junto a su tío Pedro Roldán el Mozo, o su primo, el ya aludido Pedro Duque Cornejo ${ }^{2}$.

Hacia 1721, según declaraba en un poder para testar otorgado en 1769 , debió casarse con Luisa Rivera en la iglesia de San Juan de la Palma. Tan sólo tuvieron un hijo, el también escultor Manuel Roldán Villavicencio y Rivera, existiendo testimonio de su carácter pendenciero ${ }^{3}$. Hacia mediados de siglo, Jerónimo Roldán contrajo nuevas nupcias con Rosa Valera y Alvey, quien falleció en 1758 sin dejar descendencia. Su tercer matrimonio con María de Santa María y Zabala tuvo lugar en 1771 , ya en el ocaso de su vida ${ }^{4}$.

A tenor de la documentación conservada, Jerónimo Roldán Villavicencio, que así solía firmar adoptando como propios los dos apellidos paternos, prestó mayor atención a los negocios que a los quehaceres escultóricos. Sin duda, era una manera de obtener pingües y constantes beneficios económicos, que le permitieron una vida desahogada, sin necesidad de someterse a los vaivenes del mercado artístico ni de entrar en continua competencia con otros escultores, dotados quizás de mayor genio que él.

De hecho, sabemos que en 1740 arrendó una yeguada para trillar la finca y sementera que poseía en el término de la villa de Guillena ${ }^{5}$. Veinte años después lo encontramos como Visitador de la Ronda de los Millones y dueño, junto a Manuel Salgado, de un telar de medias que arrendaban con frecuencia ${ }^{6}$. A partir de 1764, Jerónimo Roldán figura como Administrador de las Rentas del Aguardiente en

1. El capitán Marcelino Roldán, caballero del hábito de San Juan de Letrán, otorgó a su esposa poder para testar, el 30 de mayo de 1709. Josefa de Serrallonga otorgó dicho testamento el 1 de julio del citado año. La transcripción completa de estos documentos la realizó María Salud Caro Quesada en Noticias de Escultura (1700-1720). Sevilla, 1992, pp. 159-161.

2. SANCHO CORBACHO, Heliodoro: El escultor sevillano Pedro. Roldán y sus discípulos. Sevilla, 1950, pp. 39-40. Estas conclusiones con respecto a su aprendizaje las hace extensivas a los tres hermanos escultores.

3. Ibidem, p 40. Inserta un completo apéndice documental referido a Jerónimo Roldán en las páginas 112-118. Su hijo Manuel Roldán se casó con Gabriela de la Jara hacia 1755, teniendo tres hijos: Ignacia, Miguel y Demetrio. Gabriela murió el 16 de diciembre de 1763.

4. Ibid, pp. 116-117. Jerónimo Roldán conocía de varios años atrás a la que en 1771 convirtió en su esposa. El poder para testar de 1769 lo otorga Jerónimo en favor de su hijo Manuel y de María de Santa María, a la que deja un importante legado de 100 ducados "por lo mucho que se a esmerado con nosotros, a la que atenderá el referido mi hijo en cuanto le sea posible"; asimismo, la nombra como una de sus albaceas testamentarias, e incluso como tutora de sus tres nietos.

5. Ibid, p. 113.

6. Ibid, pp. 114-115. 
Sevilla y La Rinconada, mientras que su hijo Manuel desempeña el cargo de Visitador de la Ronda del Aguardiente ${ }^{7}$.

Su muerte acaeció en torno a 1780 , enterrándose en la parroquia de San Marcos, collación donde transcurrió prácticamente toda su existencia, y de cuya Hermandad Sacramental era cofrade ${ }^{8}$.

\section{2.- SU OBRA ESCULTORICA.}

Hasta el momento presente, el catálogo escultórico de Jerónimo Roldán se reducía a las tres imágenes que ejecutó para la Capilla del Rosario, en el barrio de los Humeros (un San Antonio de Padua en 1759, la Virgen titular y el Crucificado de la Paz en 1761), así como al ya citado grupo de temática fernandina que corona la reja de la Capilla Real, instalada en 1773.

Tan reducido elenco se ve aumentado ahora con el conocimiento de una obra, que ha permanecido inédita hasta hoy. Se trata de tres sayones o "judíos" realizados en 1730 para la señera Hermandad de Nuestra Señora del Valle. Si bien hemos de lamentar que tales efigies no se conserven, sí consideramos de interés esta aportación documental, pues nada sabíamos sobre la más temprana actividad artística de Jerónimo Roldán, engrosando la nómina de imagineros que secularmente han venido trabajando para las corporaciones penitenciales hispalenses.

\section{1.- Judíos para la Hermandad del Valle. Año 1730.}

En 1730, siendo Ambrosio de Figueroa Mayordomo de la Hermandad del Valle, se pagaron a Jerónimo Roldán 160 reales "por tres judíos que estava hasiendo, como consta de" sus resibos" 9 . Y, en efecto, en la Data de estas cuentas figuran tres comprobantes firmados por el escultor: el primero, por 60 reales, se fecha el 6 de mayo de 1730, "a quenta de un gudío que estoy asiendo para dicha Cofradía" ${ }^{10}$; el segundo lo rubrica el 13 de julio por un total de 75 reales, "a quenta del judio que estoy asiendo para la Cofradía del Christo de la Coronación" ${ }^{11}$; el tercero y último lo signa el 1 de noviembre, haciéndose cargo de 25 reales "que son los mesmos que se me deven a quenta de un gudío que estoi asiendo para dicha Cofradía" ${ }^{12}$.

7. Ibid, pp. 115-118. En abril de 1775 hubo de tomar en arrendamiento al Cabildo de la Ciudad su propia casa de la Plazuela de Valderrama, al tenerla embargada por las deudas contraídas en la referida administración de las rentas del aguardiente.

8. Ibid, pp. 40-41 y 112-118. Entre 1727 y 1731 consta su avecindamiento en la collación de Omnium Sanctorum. Al menos desde 1738, reside en la collación de San Marcos, de la que no se moverá hasta su muerte. El último documento que se conoce sobre su vida es un arrendamiento que otorgó el 3 de septiembre de 1774. Cfr. PRIETO GORDILLO, Juan: Noticias de Escultura (1761-1780). Sevilla, 1995, pp. 161-162.

9. Archivo General del Arzobispado de Sevilla. Sección Hermandades. Leg. 200. Autos sobre cuentas de la Mayordomía de Ambrosio de Figueroa. 1735-1749. Data de las cuentas de 1730-1731, f. 31r.

10. Ibidem, f. 59.

11. Ibid, f. $60 \mathrm{r}$.

12. Ibid, f. 58 . 
Tan ínfima cuantía no puede sino corresponder a las últimas partidas que se abonaron a Jerónimo Roldán por la hechura de los referidos "tres judios", encuadrándose las mismas en el proceso total de renovación del segundo paso de misterio de esta Hermandad, es decir, el que narra el encuentro del Nazareno con la Santa Mujer Verónica en la Calle de la Amargura. Desde mayo de 1730 a mayo de 1732, se destinaron a dicha labor las siguientes sumas, además de las ya citadas: 7 reales "de una tabla que se trujo para los judíos en el paso", 28 reales "en quatro tablas para las tarjetas del paso", 600 reales "que se gastaron en dorar dichas tarjetas", 120 reales "en aparejar dicho paso", 400 reales "en estofar los judíos" y 75 reales "en quatro faldones para el citado paso de Jesús con la Cruz" ${ }^{13}$.

Afortunadamente, hemos logrado localizar el recibo correspondiente al estofado de los judíos esculpidos por Jerónimo Roldán. Fue Juan Ruiz Soriano, "profesor del arte de la pintura", quien percibió el 25 de marzo de 1732 los 400 reales "en que se ajustaron el dorado y pintado de los saiones del paso de la Cofradía del Sr. de la Coronasión de Espinas que sale del Convento del Balle desta ciudad de Sevilla" ${ }^{14}$. Sugestiva resulta esta faceta como pintor de imaginería del murillesco Juan Ruiz Soriano (Higuera de la Sierra, 1701-Sevilla, 1763). Quizás no fue ésta la única colaboración entre ambos artistas, pues sabemos que Jerónimo no solía policromar sus obras.

En 1852, González de León nos describe la configuración del misterio de la Verónica: "Va el Señor cargado con la cruz, ayudado de Simón Cirineo, y delante, de rodillas, la Verónica con el lienzo de haber limpiado el rostro del Salvador. Multitud de figuras abruman este paso, que si fueran buenas podrían disculparse; pero ninguna vale nada, a escepción de la Verónica, que es de Montañés, y el Señor, que aunque muy antiguo, es regular. Van varios judíos, las mugeres de Jerusalén, a quien Jesucristo mandó que no llorasen, van los ladrones y dos ángeles con faroles" ${ }^{15}$.

Unos años después, en 1882, Bermejo y Carballo es algo más condescendiente en su valoración de esas figuras secundarias, calificándolas de "apreciables". Además, certifica que las mujeres de Jerusalén habían sido realizadas en 1805 por Juan Bautista Petroni, y que recientemente se habían añadido al paso "dos soldados romanos, uno de ellos con el Senatus". Sin embargo, lo que más nos interesa es que cita "un judío con una trompeta" y dos sayones que conducían a los ladrones maniatados, identificándonos así las actitudes de los tres judíos de Jerónimo Roldán ${ }^{16}$.

La prensa del año 1903 se hace eco de la remodelación de este misterio, "el cual hacía años que no salía y ha sido por completo restaurado, suprimiéndosele tres figuras" ${ }^{17}$. Cinco años más tarde, Pérez Porto no introduce variantes en su

13. Ibid, fs. $31 \mathrm{r}-35 \mathrm{v}$.

14. Ibid, f. 65.

15. GONZALEZ DE LEON, Félix: Historia crítica y descriptiva de las cofradías de penitencia, sangre y luz, fundadas en la ciudad de Sevilla. Sevilla, 1852, p. 61.

16. BERMEJO Y CARBALLO, José: Glorias Religiosas de Sevilla. Sevilla, 1882, p. 176.

17. Diario El Liberal. Sevilla, 10 de abril de 1903, s.p. 
descripción del paso, con respecto a la efectuada años atrás por Bermejo ${ }^{18}$. Sin embargo, consta que en 1918 este misterio ya había adquirido su configuración actual ${ }^{19}$, a saber: el Nazareno, escultura anónima sevillana de la segunda mitad del siglo XVII, la Verónica efigiada por Andrés Rossi en 1815 y el grupo de las tres Santas Mujeres, realizado por Juan Bautista Petroni en 1799 -antigua Magdalena- y $1805^{20}$.

\section{2.- San Antonio de Padua. Capilla del Rosario de los Humeros. Año 1759.}

Enrique Gómez Millán, en un breve artículo publicado en 1928, daba a conocer la paternidad de Jerónimo Roldán sobre tres esculturas realizadas para la Capilla del Rosario de los Humeros ${ }^{2 !}$. La primera, siguiendo un orden cronológico, es la de San Antonio de Padua, fechada en 1759. La historiografía decimonónica apenas se ocupó de ella. Tan sólo la cita Gestoso en un "altar moderno" del lado del Evangelio ${ }^{22}$. En nuestros días, conocida ya su autoría, vuelven a reseñar escuetamente su existencia Alberto Villar ${ }^{23}$, Jorge Bernales ${ }^{24}$ y Juan Martínez Alcalde ${ }^{25}$, entre otros. Sin duda, ha sido Romero Mensaque quien se ha ocupado más detalladamente de su estudio, divulgando todos los pormenores documentales referidos a este grupo de imágenes ${ }^{26}$.

El 8 de abril de 1759, Jerónimo Roldán Serrallonga recibió de Miguel de Liñán, Mayordomo de la Hermandad de Nuestra Señora del Rosario de los Humeros, 500 reales por la hechura en blanco de este San Antonio de Padua ${ }^{27}$.

18. PEREZ PORTO, Luis C.: Relación e Historia de las Cofradías sevillanas desde su fundación hasta nuestros días. Sevilla, 1908, p. 28; NOEL, Eugenio: Semana Santa en Sevilla. Sevilla, 1991, p. 45. En su estudio introductorio, Jiménez Barrientos y Gómez Lara indican que la restauración de 1903 la llevó a cabo el escultor Emilio Pizarro y Cruz, quien volvio a intervenir en 1905.

19. EL BUEN COPISTA: "Curiosidades del Buen Copista (28)" en Boletín de las Cofradías de Sevilla, $n^{\circ}$ 121. Sevilla, octubre de 1969, pp. 8-9.

20. MONTOTO, Santiago: Cofradias Sevillanas. Sevilla, 1976, p. 127; GONZALEZ GOMEZ, Juan Miguel y José RODA PEÑA: Imaginería procesional de la Semana Santa de Sevilla. Sevilla, 1992, pp. 123-124.

21. GOMEZ MILLAN, Enrique: "El escultor Jerónimo Roldán" en Sevilla y la Semana Santa. Sevilla, 1928, pp. 59-60. Como veremos, se equivocó al fechar las tres imágenes en 1759, error en el que se ha incurrido posteriormente con frecuencia. Se cita este artículo en THIEME-BECKER: Künstler-Lexicon. Leipzig, 1939, pp. 532-533.

22. GESTOSO Y PEREZ, José: Sevilla Monumental y Artística. T. III. Sevilla, 1892, p. 427.

23. VILLAR MOVELLAN, Alberto: "Imagineros sevillanos del siglo XVIII" en Boletín de las Cofradias de Sevilla, $\mathrm{n}^{\circ} 241$. Sevilla, octubre de 1979, p. 24.

24. BERNALES BALLESTEROS, Jorge y Federico GARCIA DE LA CONCHA DELGADO: Imagineros andaluces de los Siglos de Oro. Sevilla, 1986, p. 89.

25. MARTINEZ ALCALDE, Juan: Hermandades de Gloria de Sevilla. Sevilla, 1988, pp. 302-303.

26. ROMERO MENSAQUE, Carlos José: El Rosario en Sevilla. Religiosidad popular y Hermandades de Gloria. Sevilla, 1990, p. 143; IDEM: El Rosario de los Humeros. Estudio histórico y patrimonial de la Hermandad de Ntra. Sra. del Rosario y Santo Cristo de la Paz. Sevilla, 1993, pp. 53-55.

27. ROMERO MENSAQUE, Carlos José: El Rosario de los Humeros. Estudio histórico y patrimonial de la Hermandad de Ntra. Sra. del Rosario y Santo Cristo de la Paz. Op. cit., pp. 54-55. 
Una vez más, el escultor no se encarga de la policromía de su obra, pero esta vez desconocemos el nombre de quien pudiera haber acometido dicha labor.

La imagen se conserva sobre una repisa de madera tallada y dorada con ornamentación de rocallas, en el muro de la Epístola del recinto. El Santo francisccano se muestra erguido, mide 1,40 metros de alto, y lleva sobre sus brazos al Niño Jesús, que dirige su mirada al espectador. El Pequeño Infante jueguetea sobre el blanco pañal y el libro que porta San Antonio en su mano izquierda; su actitud es muy dinámica y, desde el punto de vista morfológico, presenta gran semejanza con el Niño Jesús de la Virgen del Rosario de esta misma Capilla. Los rostros son inexpresivos, aunque poseen la candorosidad propia de la escultura rococó.

\section{3.- Nuestra Señora del Rosario. Capilla del Rosario de los Humeros. Año 1761.}

En 1844, González de León señalaba que en la ermita de los Humeros nada se conservaba de interés, "a excepción de la imagen titular, Nuestra Señora del Rosario, que está sentada y es por el estilo de las imágenes que hacía Ita del Castillo" ${ }^{28}$. Esta adscripción a la estética del escultor dieciochesco Benito de Hita y Castillo (1714-1784) la mantiene un lustro después Pascual Madoz ${ }^{29} \mathrm{y}$, posteriormente, Serrano y Ortega ${ }^{30}$. Gestoso, más fino en sus apreciaciones estilísticas, en 1892 cataloga la talla mariana como "obra de regular mérito del siglo XVIII, pero en mal estado, por las restauraciones" ${ }^{31}$.

Gómez Millán, como sabemos, rescató la figura de Jerónimo Roldán como autor de las tres esculturas de los Humeros. Buen observador, señaló el parentesco iconográfico existente entre esta Virgen del Rosario y la de la Paz, venerada en la parroquia de Santa $\mathrm{Cruz}^{32}$. Martínez Alcalde, estudioso infatigable de las Hermandades sevillanas de Gloria, facilitó la fecha exacta de su realización, en 1761 , pues antes se venía señalando la de $1759{ }^{33}$. Pero, una vez más, será Romero Mensaque quien nos facilite el pertinente aval documental ${ }^{34}$.

28. GONZALEZ DE LEON, Félix: Noticia Artística de Sevilla. Sevilla, 1844, p. 491.

29. MADOZ, Pascual: Diccionario Geográfico-Estadístico-Histórico de España y sus posesiones de ultramar. T. XIV. Madrid, 1849, p. 332. "La Virgen titular se halla sentada, y es una imagen por el estilo de las de Ita del Castillo".

30. SERRANO Y ORTEGA, Manuel: Noticia histórico-artística de la sagrada imagen de Jesús Nazareno, que con el título del Gran Poder se venera en su capilla del templo de San Lorenzo de esta ciudad. Sevilla, 1898, p. 107.

31. GESTOSO Y PEREZ, José: Sevilla Monumental y Artística. T. III. Op. cit., p. 427.

32. GOMEZ MILLAN, Enrique: "El escultor Jerónimo Roldán". Op. cit., p. 60.

33. MARTINEZ ALCALDE, Juan: Hermandades de Gloria de Sevilla. Op. cit,, p. 301; IDEM: Imágenes sevillanas de la Virgen. Sevilla, 1991, p. 134. En este estudio el autor vuelve, sin duda por olvido involuntario, a la fecha de 1759.

34. ROMERO MENSAQUE, Carlos José: El Rosario en Sevilla. Religiosidad popular y Hermandades de Gloria. Op. cit., pp. 141-142; IDEM: El Rosario de los Humeros. Estudio histórico y patrimonial de la Hermandad de Ntra. Sra. del Rosario y Santo Cristo de la Paz. Op. cit., pp. 53-54. 
El Mayordomo Miguel de Liñán abonó 300 reales el 6 de febrero de 1761 a Jerónimo Roldán, por haber ejecutado "una Virgen con su niño... todo en blanco". Un año y medio más tarde, el 26 de julio de 1762, el pintor Joaquín Cano percibía 120 reales por el trabajo de encarnar y estofar diversas imágenes de la Capilla de los Humeros, entre las que se encontraba la de Nuestra Señora del Rosario ${ }^{35}$. Resulta interesante esta aportación a la obra de Joaquín Cano, cuya personalidad y producción no es excesivamente conocida; Valdivieso lo sitúa entre los discípulos y seguidores de Juan de Espinal, laborando en la segunda mitad del siglo XVIII ${ }^{36}$. Quizás también se le pueda adjudicar el estofado de la imagen de San Antonio de Padua, ejecutada según veíamos por Jerónimo Roldán en 1759 , aunque ello sea una mera posibilidad.

El 23 de marzo de 1761, tan sólo unos días después de que Jerónimo Roldán concluyera la imagen mariana, se bendijo solemnemente la Capilla que se le consagró en el arrabal de los Humeros ${ }^{37}$. La efigie preside el retablo mayor del recinto, que se concertó el 1 de marzo de 1764 por el maestro ensamblador Lorenzo Pérez Caballero, y cuyo coste de 8.000 reales fue patrocinado por el devoto Alonso Valcázar Monsalves, vecino de la collación de San Vicente ${ }^{38}$.

La Virgen del Rosario es una escultura de bulto redondo en madera policromada, de tamaño menor al natural (mide $85 \mathrm{cms}$. de alto). Por fortuna, nunca ha sido mutilada, a pesar de que ocasionalmente, sobre todo con motivo de su salida procesional matutina en el mes de octubre, la talla se llegó a sobrevestir con toca, manto y saya.

Los precedentes iconográficos de esta imagen debemos buscarlos en dos efigies de la misma advocación, que se vinculan al quehacer del escultor manierista Jerónimo Hernández (1540-1586): la que hoy se venera bajo el título de Nuestra

35. ID: El Rosario de los Humeros. Estudio histórico y patrimonial de la Hermandad de Ntra. Sra. del Rosario y Santo Cristo de la Paz. Op. cit., p. 59. El recibo de Jerónimo Roldán dice así: "Recibí del hermano Miguel de Liñán trescientos reales de una Virgen con su niño, más recibí trescientos reales por cuenta de un Señor Crucificado para Vía Crucis, más cinco pesos de un niño, todo en blanco, y por ser verdad lo firmo en Sevilla, 6 febrero 1761". El de Joaquín Cano reza del siguiente modo: "Recibí del hermano Miguel de Liñán por las encarnaciones de la Virgen y del niño, la Señora como principal de la capilla de Nuestra Señora del Rosario, más por las encarnaciones de San Rafael y un Crucifijo para dicha capilla, ciento veinte reales, más por las encarnaciones de una Virgen de los Dolores y poner los ojos azules, para dicha capilla, setenta y cinco reales, más las encarnaciones de otros santos para la capilla, cincuenta reales, más por pintado y dorado de dos peanas y composición de dos niños para dicha capilla, más por corona y frontalera para dicha capilla, cincuenta reales... y para que conste su abono le doy para que lo firmen en Sevilla y julio del año de 1762".

36. VALDIVIESO, Enrique: Historia de la Pintura Sevillana. Sevilla, 1986, p. 350.

37. ROMERO MENSAQUE, Carlos José: El Rosario de los Humeros. Estudio histórico y patrimonial de la Hermandad de Ntra. Sra. del Rosario y Santo Cristo de la Paz. Op. cit., pp. 15-16.

38. PRIETO GORDILLO, Juan: Noticias de Escultura (1761-1780). Op. cit., pp. 141-142. 
Señora de la Paz, en la parroquia de Santa Cruz, fechada hacia $1577-1578^{39}$, y la de la Capilla del Museo, de similar cronología ${ }^{40}$. En efecto, nos encontramos ante una trilogía de esculturas rosarianas sedentes, cuya principal singularidad radica en sostener al Niño Jesús sobre su rodilla derecha, quien se muestra erguido y portando una cruz latina.

La Virgen de los Humeros fue restaurada en 1986 por José Manuel Bonilla Cornejo, quien rescató su primitiva encarnadura, eliminó repintes y limpió de barnices oxidados el suntuoso estofado de su indumentaria. Además, tras un detallado estudio de la imagen, apuntó la posibilidad de que ésta fuera anterior al año 1761, limitándose Jerónimo Roldán a remodelar una talla anterior ${ }^{41}$. Sea como fuere, lo que verdaderamente interesa destacar es que el aspecto externo de la efigie responde a la estética dieciochesca de Jerónimo Roldán.

La escultura, concebida para estar entronizada en un rico sitial, presenta el dorso menos elaborado que su frente. El rostro mariano, ancho y de contorno redondeado, se enmarca por una frondosa cabellera, de la que pende un grueso mechón sobre el hombro diestro. La sonriente faz de la Virgen hace gala de una extraordinaria dulzura, y sus rasgos aniñados subrayan su filiación rococó. Viste túnica roja, ajustada a la cintura con cíngulo dorado; la caída del manto azul desde el hombro derecho hasta las plantas, describiendo con el pico un triángulo frontal, es un elemento tomado de los aludidos modelos quinientistas. El pie derecho asoma por debajo de los ondulantes pliegues de la túnica. Debemos resaltar la belleza y calidad del estofado, a base de rocallas y motivos florales, que acredita la valía de Joaquín Cano para estos menesteres. En la mano izquierda sustenta un cetro de plata, mientras que con la derecha parece agarrar al Niño Jesús, que se resbala por la rodilla materna, vestido únicamente con un áureo pañal; la dinámica orientación de sus piernas, la izquierda más elevada que la contraria, se contrapone

39. HERNANDEZ DIAZ, José: "Iconografía de la Virgen Madre en la escultura renacentista" en Archivo Hispalense, números 3 y 4. Sevilla, 1944, p. 36; IDEM: Imaginería hispalense del Bajo Renacimiento. Sevilla, 1951, pp. 63-64; RODA PEÑA, José: "Esculturas marianas hispalenses de raigambre marinera" en Actas de las IX Jornadas de Andalucía y América. Sevilla, 1991, pp. 330-332. Era venerada bajo la advocación de Nuestra Señora del Rosario en su capilla propia del convento dominico de San Pablo. Tras la desamortización de Mendizábal en 1835, se trasladó a la iglesia parroquial de Santa Cruz, donde hoy recibe culto en el baldaquino de la capilla mayor.

40. GONZALEZ GOMEZ, Juan Miguel: "Jerónimo Hernández, fundador de la escuela escultórica sevillana" en Catálogo de la Exposición Jerónimo Hernández y la escultura del Manierismo en Andalucía y América. Sevilla, 1986, s.p.; MARTINEZ ALCALDE, Juan: Imágenes sevillanas de la Virgen. Op. cit., p. 129.

41. MARTINEZ ALCALDE, Juan: Hermandades de Gloria de Sevilla. Op. cit., p. 301; ROMERO MENSAQUE, Carlos José: El Rosario en Sevilla. Religiosidad popular y Hermandades de Gloria. Op. cit., p. 142; IDEM: El Rosario de los Humeros. Estudio histórico y patrimonial de la Hermandad de Ntra. Sra. del Rosario y Santo Cristo de la Paz. Op. cit., pp. 14-15 y 53-54. Consta documentalmente que la primitiva titular de la corporación de los Humeros recibía culto "en un hueco sobre la tapia del Colegio de San Laureano, conociendo la dicha Hermandad que por ser tan estrecho, está con poca decencia y las luces que se ponen se apagan luego con el viento" (1747). 
a la de sus manos, la derecha portando una cruz de nácar y plata, mientras que la siniestra, extendida hacia el fiel, sujeta las cuentas del rosario. Las coronas procesionales fueron labradas en plata sobredorada por Manuel de los Ríos en 1990, siguiendo el diseño de José Manuel Bonilla.

\section{4.- Crucificado de la Paz. Capilla del Rosario de los Humeros. Año 1761.}

Jerónimo Roldán esculpió la imagen del Cristo de la Paz en 1761. El 6 de febrero del citado año recibió "trescientos reales por cuenta de un Señor Crucificado para Vía Crucis" ${ }^{42}$. Tal funcionalidad justifica su reducido tamaño, $85 \mathrm{cms}$. de alto, adecuado para que una persona pueda portarlo en dicho ejercicio cuaresmal, como sigue aconteciendo en la actualidad. Año y medio después, en julio de 1762, se encargaba de encarnarlo Joaquín Cano, englobando su coste entre otras partidas que sumaron 120 reales ${ }^{43}$.

Según acredita un inventario de 1784 , contó con altar propio en la Capilla ${ }^{44}$; posteriormente, ocupó el manifestador del retablo mayor, presidiendo en nuestros días el antiguo altar de Nuestra Señora del Carmen, en el lado de la Epístola.

Gómez Millán, en 1928, encontraba semejanzas formales, a nuestro parecer injustificadas, entre este Cristo y el de la Salud de San Bernardo, que fue destruido en $1936{ }^{45}$. La valoración más ajustada de esta obra la realizó en 1979 el profesor Villar Movellán, para quien el Crucificado de la Paz "encaja perfectamente dentro del estilo familiar, pero revela ya las suavidades formales de mediados de siglo, patentes por ejemplo en el perizoma caído, resguardado de los fuertes y dramáticos vientos que hacían moverse el sagrado paño cincuenta años antes. Incorrecto de proporciones, está analizado no obstante con esmero en las partes fundamentales de su anatomía" 46.

Jerónimo Roldán representó un Cristo muerto, fijo a una cruz arbórea mediante tres clavos, montando el pie derecho sobre el izquierdo. Sobre el stipes o madero vertical campea el titulus o tablilla, donde figuran inscritas las características iniciales I.N.R.I. El cuerpo inerte de Jesús pende ostensiblemente del patíbulo martirial; su anatomía, de miembros enjutos, está tratada armoniosamente. Un escueto paño de pureza cordífero se ajusta a las caderas del Redentor, anudándose al lado diestro, mientras la cadera izquierda queda al descubierto. El sereno rostro,

42. ROMERO MENSAQUE, Carlos José: El Rosario de los Humeros. Estudio histórico y patrimonial de la Hermandad de Nira. Sra. del Rosario y Santo Cristo de la Paz. Op. cit., pp. 54 y 59.

43. Ibidem.

44. ROMERO MENSAQUE, Carlos José: El Rosario de los Humeros. Estudio histórico y patrimonial de la Hermandad de Ntra. Sra. del Rosario y Santo Cristo de la Paz. Op. cit., p. 60. Inventario de 17 de mayo de 1784. "En el altar de el Señor Crucificado con el título de la Pas ay una Señora de Dolores con 2 candeleros de 3 quartas y un atril plateados, 2 candeleros de metal y una crus de palo, unos manteles".

45. GOMEZ MILLAN, Enrique: "El escultor Jerónimo Roldán". Op. cit., p. 60.

46. VILLAR MOVELLAN, Alberto: "Imagineros sevillanos del siglo XVIII". Op. cit., p. 24. 
de nobles facciones muy en la línea del taller Roldán, se reclina plácidamente sobre el pecho. Antaño llegó a lucir potencias y corona de espinas. En este Crucificado se ha desterrado todo efecto dramático, dominando la serenidad y el equilibrio compositivos.

Esta escultura precisa una adecuada restauración, que resane ensambles, reponga las leves pérdidas en el soporte lígneo y reintegre las lagunas de la policromía. Bien lo merece el que pudiera considerarse como el último Crucificado roldaniano de la escuela escultórica sevillana.

\section{5.- Entrega de las llaves de Sevilla a San Fernando. Reja de la Capilla Real de la Catedral de Sevilla. Hacia 1770-1773.}

Aunque desde fines del siglo XVIII ya se emitieron juicios críticos acerca de la reja de la Capilla Real de la Catedral hispalense, y sobre las esculturas que la coronaban, fue Justino Matute el primero que identificó a Jerónimo Roldán como autor de las mismas ${ }^{47}$, pues González de León, unos años antes, lo había confundido con "un tal Gerónimo Hernández" ${ }^{48}$.

Se conserva el diseño de esta reja, un dibujo a tinta y aguada firmado por Sebastián Van der Borcht el 26 de agosto de 1766, haciéndose constar que "es la copia arreglada a el aprobado por el Rey en 3 de Mayo de 1765 que se debe executar exactamente esta vista" ${ }^{49}$. En su friso superior corre la siguiente inscripción: "SE HIZO POR MANDADO DE NTRO. REY EL SEÑOR DON CARLOS III Y A EXPENSA DE SU REAL ERARIO. AÑO DE 1773" (lado exterior), "LIBERTO DIOS A SEVILLA DEL MAHOMETANO POR MEDIO DEL JUSTO Y SANTO REY DON FERNANDO $3^{\circ}$ AÑO DE 1248" (lado interno) ${ }^{50}$. Existen testimonios afirmando que el primer decreto dictado por Carlos III al subir al trono español fue la construcción de esta reja ${ }^{51}$, que en opinión del profesor Alfredo Morales "destaca más por su grandiosidad que por sus valores artísticos, pese a ser un magnífico ejemplo de la rejería barroca" ${ }^{52}$, calificándola como "la más monumental de la Catedral y la que posee más claro sentido arquitectónico" ${ }^{53}$.

Según parece, el coste general de la reja ascendió a 11.000 pesos, de los que 43.000 reales correspondieron al valor de las esculturas del remate, ejecutadas

47. MATUTE Y GAVIRIA, Justino: Anales eclesiásticos y seculares de la Muy Noble y Muy Leal ciudad de Sevilla. T. II. Sevilla, 1887, p. 231.

48. GONZALEZ DE LEON, Félix: Noticia Artística de Sevilla. Op. cit., p. 302.

49. MORALES MARTINEZ, Alfredo J.: "Artes aplicadas e industriales en la Catedral de Sevilla" en La Catedral de Sevilla. Sevilla, 1984, p. 567; FALCON MARQUEZ, Teodoro: Catálogo de la Exposición Fernando III, Rey de Sevilla. Sevilla, 1994, s.p.

50. MORALES MARTINEZ, Alfredo J.: La Capilla Real de Sevilla. Sevilla, 1979, pp. 57-58.

51. GONZALEZ DE LEON, Félix: Noticia Artística de Sevilla. Op. cit., p. 302.

52. MORALES MARTINEZ, Alfredo J.: La Capilla Real de Sevilla. Op. cit., p. 96.

53. MORALES MARTINEZ, Alfredo J.: "Artes aplicadas e industriales en la Catedral de Sevilla". Op. cit., p. 567. 
en madera recubierta de plomo por Jerónimo Roldán ${ }^{54}$. El grupo escultórico, de composición triangular y tamaño mayor al natural, representa en el vértice superior a San Fernando ecuestre, como nuevo Santiago matamoros, cuyo equino pisotea una figura de sarraceno que blande una espada. El Santo Rey, que sujeta las riendas de su caballo con la mano izquierda al par que alza la espada con la diestra, recibe las llaves de la ciudad de Sevilla por parte del rey almohade Axataf, quien se muestra arrodillado y tocado con turbante; a la derecha, aparece un musulmán genuflexo con las manos atadas a la espalda; por último, en los extremos de la reja, se sitúan otras dos efigies sedentes de infieles maniatados.

Resulta interesante constatar, según apunta Jesús Palomero, que la fuente iconográfica de dicho conjunto escultórico es la portada del libro Memorial de inserciones genealógicas tocantes a la casa y más antiguo solar de Saavedra, escrito por Fernando Saavedra Rivadeneira, y publicado en Granada en 1674; su frontispicio procedía, a su vez, del grabado abierto en 1610 por Diego de Astor con el tema de Santiago Matamoros ${ }^{55}$.

Pocos años después de su ejecución, estas esculturas fueron valorándose negativamente por parte de la crítica artística, esgrimiendo para ello argumentos estilísticos e iconográficos. La mayoría de los mismos responden a una mentalidad ilustrada y academicista que identifica las ampulosas formas tardobarrocas con la degeneración de las Artes y la encarnación del "mal gusto".

En 1780, transcurridos tan sólo siete años desde que se colocara la reja, Antonio Ponz nos comenta que "sobre ella hay una estatua de San Fernando a caballo, y Moros encadenados, con otras cosas, todo ello de madera cubierto de plomo. Esta es la materia, ¿y la forma?. Basta oir a los mismos sevillanos inteligentes, que ven aumentados los motivos de la justa crítica que merecen las obras de los templos, donde se miró poco a la propiedad del Arte" ${ }^{56}$.

A tales figuras, González de León les atribuyó en 1844 "mezquino mérito"; además, piensa "que el autor de ellas o ignoraba la historia, o variándola a su gusto con poco decoro, al Santo conquistador lo puso a caballo, cuando consta de la historia que entró a pie comboyando a la imagen, o imágenes de Ntra. Sra. que venían presidiendo la triunfal entrada" ${ }^{57}$. Ese mismo año, Amador de los Ríos les concedió "escaso mérito", "por cuya razón no malgastaremos el tiempo describiéndolas" 58 .

54. PONZ, Antonio: Viage de España. T. IX. Madrid, 1780, p. 35; GONZALEZ DE LEON, Félix: Noticia Artística de Sevilla. Op. cit., p. 302; MATUTE Y GAVIRIA, Justino: Anales eclesiásticos y seculares de la Muy Noble y Muy Leal ciudad de Sevilla. T. II. Op. cit., p. 231; GESTOSO Y PEREZ, José: Sevilla Monumental y Artística. T. II. Sevilla, 1890, p. 321.

55. PALOMERO PARAMO, Jesús M.: "El Rey Axataf entrega a San Fernando las llaves de Sevilla" en Catálogo de la Exposición Magna Hispalensis. El Universo de una Iglesia. Sevilla, 1992, p. 186.

56. PONZ, Antonio: Viage de España. T. IX. Op. cit., p. 35.

57. GONZALEZ DE LEON, Félix: Noticia Artística de Sevilla. Op. cit., p. 302.

58. AMADOR DE LOS RIOS, José: Sevilla Pintoresca. Sevilla, 1844, p. 123. 
El único juicio positivo que podemos citar es el que emitió Justino Matute en sus Anales publicados en 1887, cuando afirma que el grupo escultórico "es superior a su fama" 59 .

A nuestro juicio, resulta justo consignar la mediocre calidad artística que presentan estas esculturas, en parte justificada por el material con que están realizadas, así como por la altura a la que se encuentran colocadas. Si comparamos el aludido diseño de Van der Borcht con el resultado final conseguido por Jerónimo Roldán, observaremos en las figuras un mayor estatismo. En el proyecto, por ejemplo, el caballo de San Fernando se representa ejecutando una cabriola, mientras que la escultura sólo levanta el cuarto delantero izquierdo; las demás figuras también se dibujaron con mayor dinamismo que el transmitido por Jerónimo. En cualquier caso, hemos de reseñar que su valor es eminentemente decorativo, logrando infundir esa magnificencia con que se pretendía dotar a esta reja que cierra tan regio recinto sagrado.

En conclusión, la figura de Jerónimo Roldán aparece ante nosotros como la de un artista discreto. Ello se evidencia si comparamos su obra conocida hasta el momento con la de otros imagineros dieciochescos, pero de una generación anterior, como Duque Cornejo o Montes de Oca, o con la de escultores rigurosamente contemporáneos, caso de Benito de Hita y Castillo o el portugués Cayetano de Acosta. Lo que sí tienen en común todos ellos es su filiación estética tardobarroca, con apuntes rococós, de un dinamismo más acusado en el caso de Duque Cornejo, Hita o Acosta, y con un atemperamiento mayor de formas en el de Montes de Oca y Jerónimo Roldán. Con seguridad, el prestigioso apellido Roldán le ayudaría a conseguir algunos encargos de cierta relevancia. En cualquier caso, la documentación conservada nos lo presenta como un conspicuo hombre de negocios, que supo compaginar la lucrativa actividad mercantil con la escultórica, sin duda más vocacional.

59. MATUTE Y GAVIRIA, Justino: Anales eclesiásticos y seculares de la Muy Noble y Muy Leal ciudad de Sevilla. T. II. Op. cit., p. 231. 


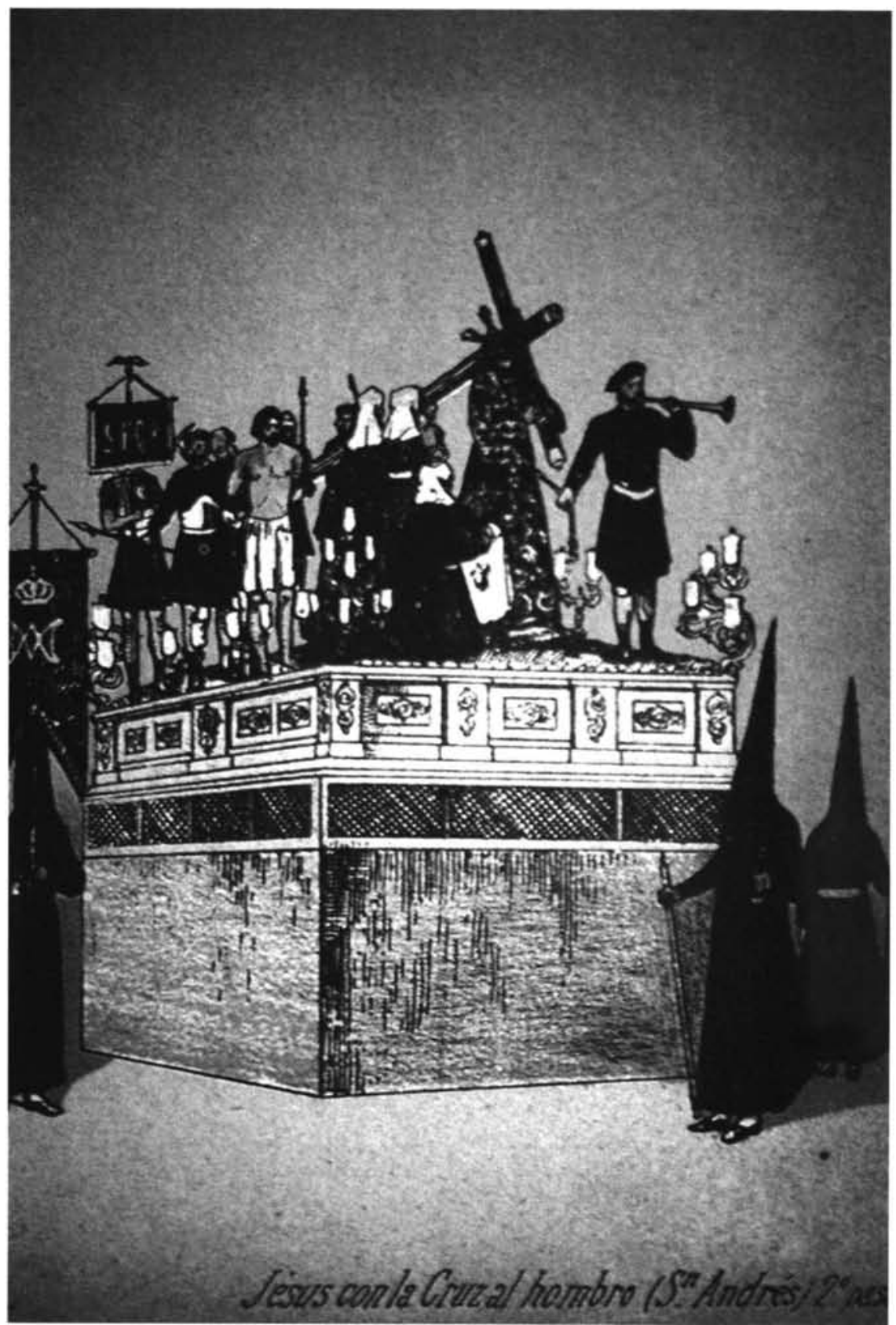

Lám. 1.- Misterio de Nuestro Padre Jesús con la Cruz al hombro. Hermandad del Valle. Sevilla. Cromolitografía de la segunda mitad del siglo XIX. 


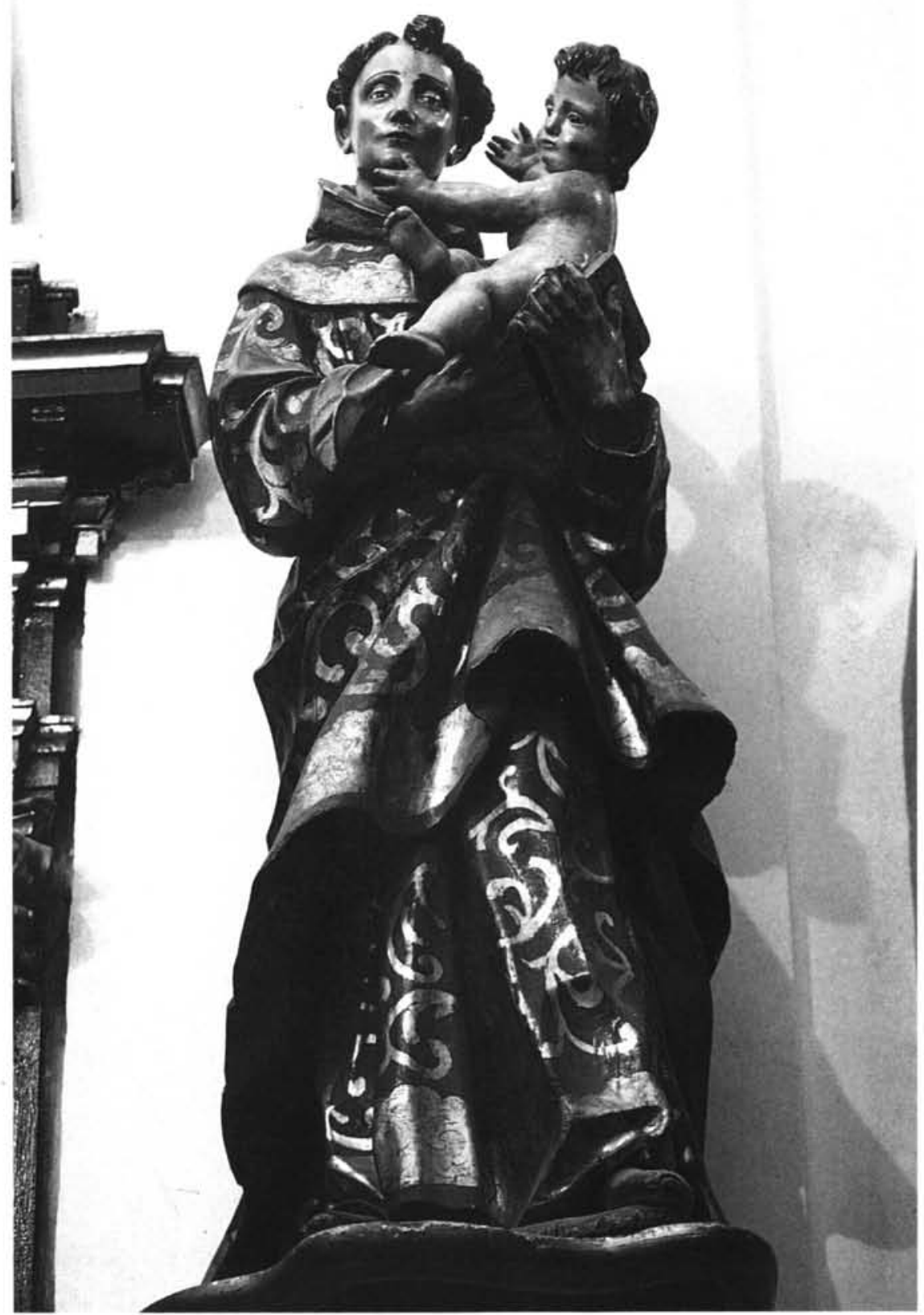

Lám. 2.- San Antonio de Padua. Obra de Jerónimo Roldán. Año 1759. Capilla del Rosario de los Humeros. Sevilla. 


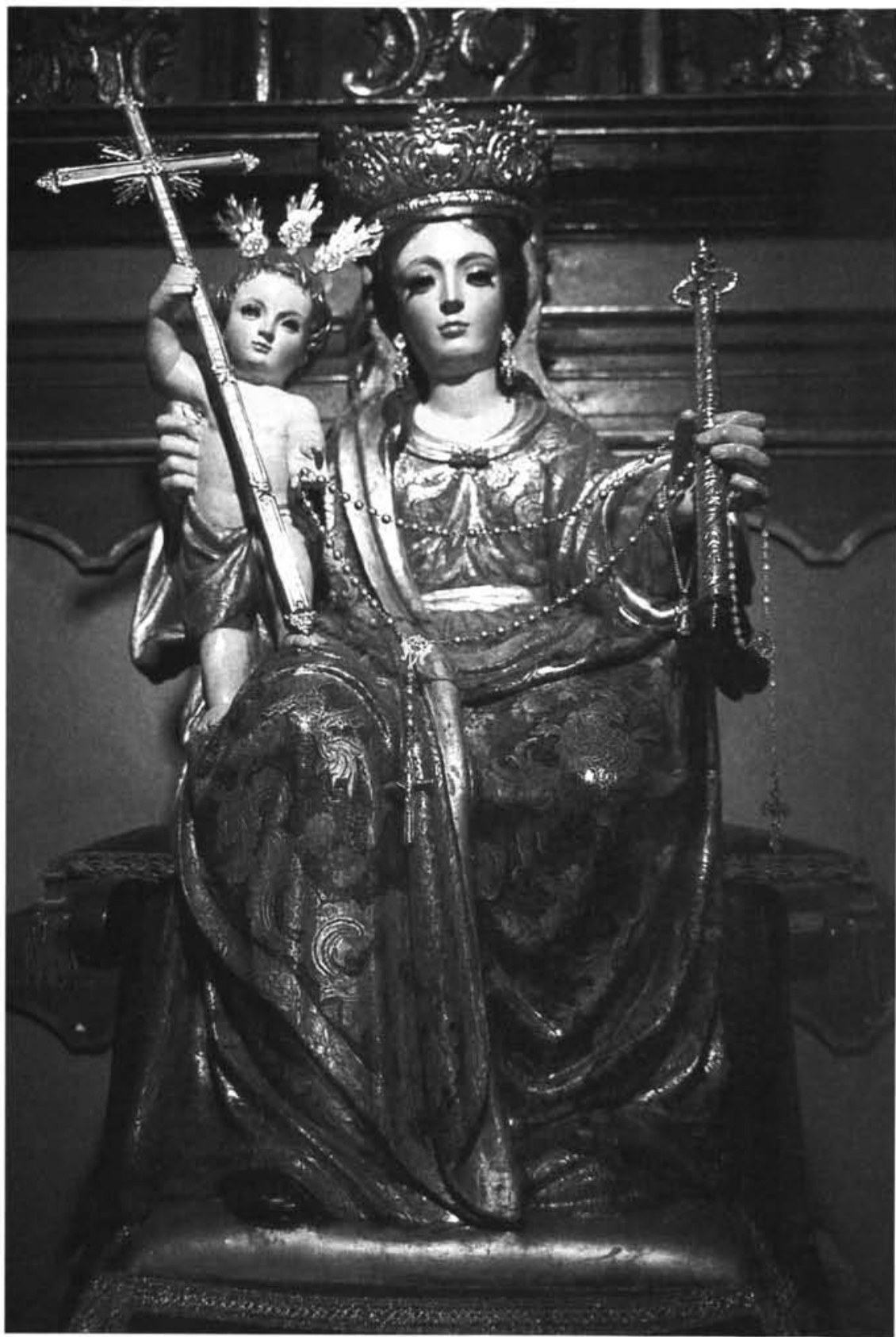

Lám. 3.- Nuestra Señora del Rosario. Obra de Jerónimo Roldán. Año 1761. Capilla del Rosario de los Humeros. Sevilla 


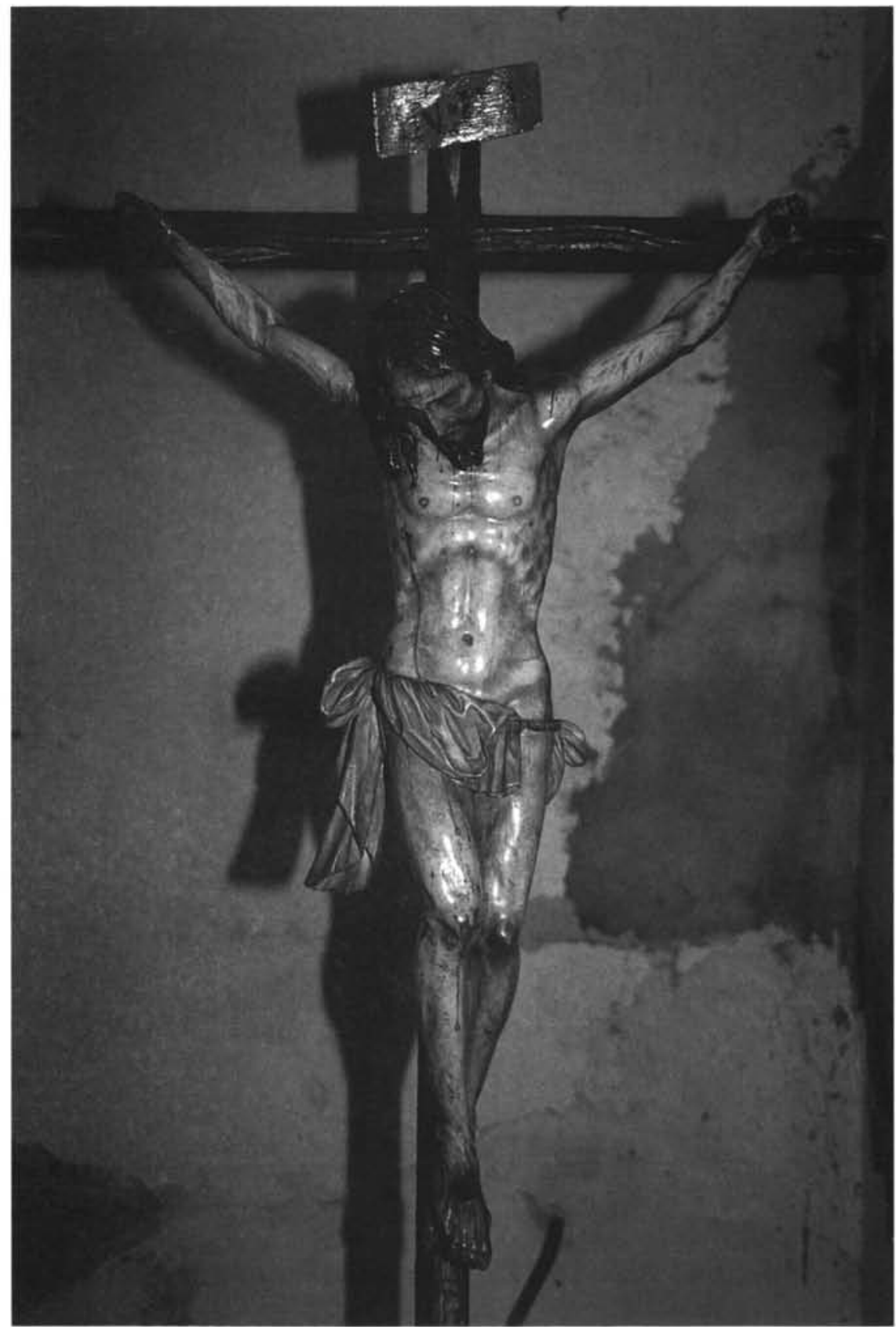

Lám. 4.- Crucificado de la Paz . Obra de Jerónimo Roldán. Año 1761. Capilla del Rosario de los Humeros. Sevilla 


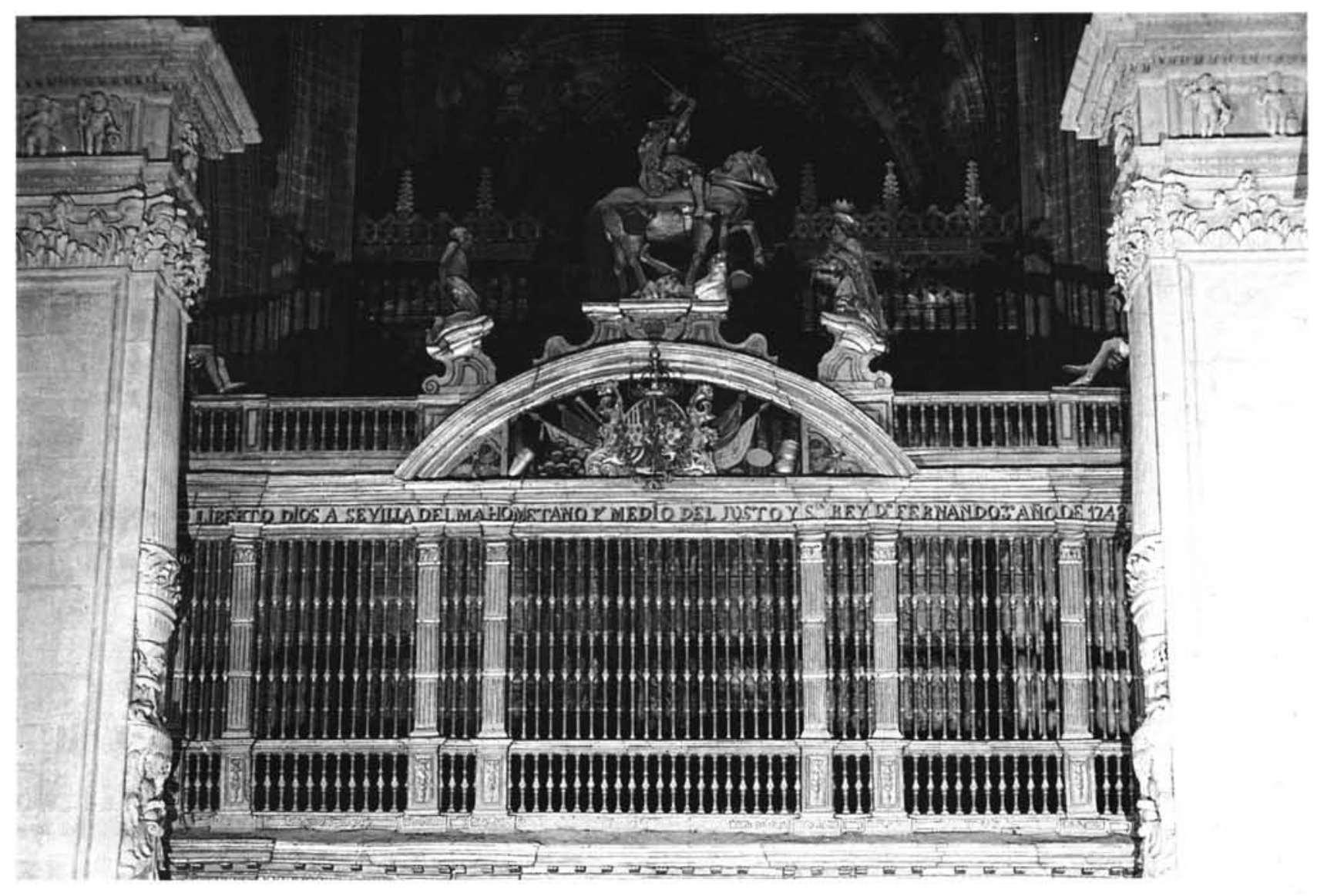

Lám. 5.- Reja de la Capilla Real de la Catedral de Sevilla. Vista desde el interior 


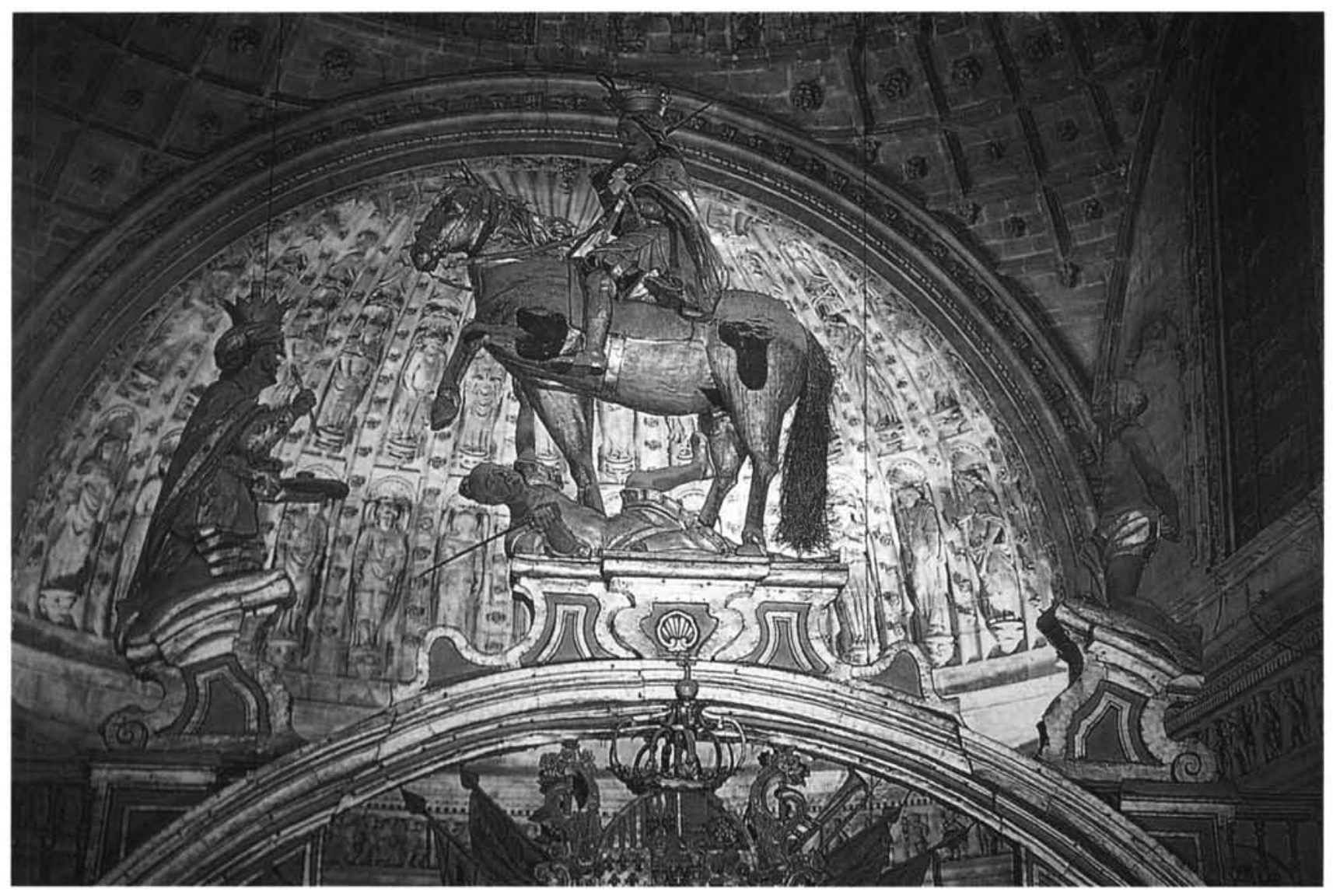

Lám. 6.- Entrega de las llaves de Sevilla a San Fernando. Reja de la Capilla Real de la Catedral de Sevilla. Obra de Jerónimo Roldán. Hacia 1770-1773. 